\title{
Notas que (trans)bordam um arquivo a conhecer ${ }^{1}$ Notes that transgress: an archive to know
}

\author{
Vanise Medeiros* \\ Raphael Mendes**
}

\section{RESUMO}

O século XIX constitui-se como um período importante para o entendimento da historicidade da língua em solo brasileiro. Ancorado no campo teórico da História das Ideias Linguísticas (Auroux) na relação com a da Análise do Discurso (Pêcheux, Orlandi), neste artigo, tem-se como objetivo dar a saber da composição de um arquivo construído a partir das notas de rodapé de Alencar em dois de seus romances, $O$ Guarani e Iracema, totalizando 202 entradas. As notas, sobre palavras e expressões, dizem respeito à língua e funcionam como verbetes. Nossa posição é a de que as notas de rodapé de Alencar se inscrevem na intensa produção de vocabulários do século XIX no Brasil, não apenas como listagens de palavras, mas no exaustivo trabalho daquele que captura, descreve e interpreta. Tal arquivo irá permitir estudos diversos sobre a língua no século XIX bem como possibilitará uma reflexão sobre o lugar do escritor na gramatização da língua em solo brasileiro.

Palavras-chave: arquivo, léxico, século XIX, Alencar.

Recebido em 30 de maio de 2020.

Aceito em 28 de agosto de 2020.

DOI: http://dx.doi.org/10.18364/rc.2021n61.442

*Universidade Federal Fluminense, Faperj, CNPq, vanisegm@yahoo.com.br, http://orcid.org/0000-0002-6998-9377

**Universidade Federal Fluminense, raphael_mendes@live.com, https://orcid.org/0000-0002-7256-0707

1 Este artigo decorre dos projetos Faperj CNE (Proc. n.o E-26/211.459/2019), CNPq (PQ, Proc. 305428/2018-7) e do projeto de Iniciação Científica PIBIC/UFF.

Confluência. Rio de Janeiro: Liceu Literário Português, n. 61, p. 66-98, jul.-dez. 2021 


\section{ABSTRACT}

The 19th century is an important period for understanding the historicity of the language on Brazilian soil. Anchored in the theoretical field of the History of Linguistic Ideas (Auroux) in relation to that of Discourse Analysis (Pêcheux, Orlandi), in this article, we aim to inform about the composition of an archive built from the footnotes of Alencar in two of his novels, $O$ Guarani and Iracema, totaling 202 entries. These notes, on words and expressions, refer to the language and act as entries. Our position is that Alencar's notes are part of the intense production of vocabularies of the 19th century in Brazil, not only as word lists, but in the exhaustive work of the one who captures, describes and interprets them. This archive will allow different studies on the language in the 19th century, as well as work on reflections on the writer's place in the grammatization of the language on Brazilian soil.

Keywords: archive, lexicon, 19th century, Alencar.

Observar a história dos documentos, os percursos que eles realizam, leva a compreender melhor a produção do conhecimento. NUNES, 2008

\section{Breves palavras acerca do arquivo}

"Um arquivo nunca é dado a priori”, nos lembra Guilhaumou e Maldidier (1997, p. 163) ao tratar, dentre outros aspectos pertinentes ao arquivo, daquele que diz respeito à leitura. Ler um arquivo, seguindo com tais autores, não decorre de uma suposta transparência dos documentos, mas de procedimentos de leitura, ou, dito de outro modo, um arquivo se constrói a partir dos dispositivos de leitura dos pesquisadores, afinal, um "arquivo não é um simples documento no qual se encontram referências; ele permite uma leitura que traz à tona dispositivos e configurações significantes.”(idem, p. 163). $\mathrm{O}$ presente artigo tem seu gérmen a partir de projetos que conjugam leitura e composição de arquivos. Por um lado, procede de leituras de textos literários do século XIX que apresentam saberes sobre língua em suas margens - o que, 
como já dito em outros trabalhos (MEDEIROS, 2017), configura um arquivo de leitura sobre língua no século XIX -; por outro lado, propõe a construção de arquivos de língua a partir de tais margens. Uma construção que, importa salientar, também pressupõe gestos teóricos e analíticos de leitura.

A perigrafia no século XIX é rica e consistente: são muitas as advertências, cartas e dedicatórias, notas ao final ou ao pé de página; são numerosos os prólogos e posfácios; são diversas as revisões com alterações e comentários do autor. Nesse diversificado material que se apresenta nas bordas dos textos se lê sobre Brasil; nele se discute sobre literatura, língua, história, para ficarmos com três dos campos deveras presentes; nele se acena para o passado e para o devir. Não passam incólumes; são relevantes para a história do conhecimento literário, social, cultural, e, para ficar com nosso interesse aqui, das línguas.

Neste artigo, temos como objetivo dar a saber da composição de um arquivo, composto a partir das notas de alguns romances indianistas de José de Alencar, bem como trazer à luz parte deste arquivo, a saber, aquela com notas dos romances $O$ Guarani e Iracema. Como já indicado em outros trabalhos (MEDEIROS, 2014, 2016, 2017, 2019), em vários dos romances de Alencar as notas se fazem presentes. Inúmeras e por vezes mais extensas que a prosa, como é caso em Ubirajara, elas constituem um acervo importante da língua: iluminam os estudos lexicográficos empreendidos pelo autor bem como possibilitam novas e necessárias pesquisas em diversos campos de conhecimento acerca da linguagem, como é o caso, para citar um exemplo, da História das Ideias Linguísticas. Em poucas palalavras, se Alencar é uma referência incontestável para a literatura brasileira, não o é sem seus estudos sobre a língua.

Nunes (2008), ao refletir sobre discurso documental, propõe uma distinção entre textos documentados e textos documentadores. Considerando a documentação linguística, os documentados seriam as obras, ao passo que os documentadores consistiriam em "descrições, comentários, resumos, indexações, bibliografias, periodizações, etc.”. As notas de Alencar fazem parte deste segundo grupo: elas glosam, tal como os comentários, portando nesta dobra 
sobre a palavra, saberes dicionarísticos e enciclopédicos (ESTEVES, 2014).

Ainda uma observação acerca do arquivo que ao final se expõe. Auroux (1992), ao tratar do nascimento das metalinguagens, nos acena para três categorias de "trabalhos consagrados à história dos conhecimentos linguísticos", quais sejam:

i. os que visam a constituir uma base documentária para a pesquisa empírica; ii. os que são homogêneos à prática cognitiva de que derivam (por exemplo, trabalho de um filólogo das línguas clássicas sobre a gramática, a filologia ou a lógica grega); iii. os que têm um papel fundador, voltando-se para passado para legitimar uma prática contemporânea." (AUROUX, 1992, p. 11)

Nossa proposta incide, diremos, sobre a primeira das categorias, isto é, pretendemos que nosso arquivo, concebido a partir das notas de Alencar, possa servir para outras pesquisas e estudos tanto sobre línguas quanto sobre produção de conhecimento.

\section{Das notas ao arquivo}

As notas bordam e transdordam os romances de Alencar. Presentes nos rodapés ou ao final, tecem margens que ampliam outras margens. Dizem da língua, dos sujeitos e de outros saberes. Inscritas em um contexto de descolonização linguística ${ }^{2}$ (Orlandi, 2002) e de gramatização da língua nacional no Brasil no século XIX ${ }^{3}$, é possível pensar as notas como instrumentos linguísticos, uma vez que

2 Num contexto de pós independência do Brasil, a unidade nacional em muito passava pela necessidade de uma língua nacional. Nesse sentido, conforme Orlandi (2002), a produção de saberes metalinguísticos "produzidos do lado de cá do Atlântico" denotam a tentativa do Brasil em ser uma nação própria e não dependente de Portugal.

3 No século XIX surgem os primeiros dicionários monolíngues no Brasil. Acerca da produção dos primeiros dicionários brasileiros, ver Nunes (2003).

Confluência. Rio de Janeiro: Liceu Literário Português, n. 61, p. 66-98, jul.-dez. 2021 


\begin{abstract}
"Marcados ou não no corpo, tais notas, sobre palavras e expressões, dizem respeito à língua, funcionam como verbetes e vão compondo glossários sobre a língua. Constituem, assim, instrumentos linguísticos, artefatos sobre a língua que, como nos fala Auroux, afetam a língua, isto é, não deixa "intactas às práticas linguísticas humanas" (AUROUX, 1992, p.70)" (MEDEIROS, 2015).
\end{abstract}

Das notas de rodapé de José de Alencar podemos dizer que fazem parte de um gesto inaugural de produção de glossários de literatura no Brasil e que nos fornecem pistas importantes para entender o processo de institucionalização da língua no Brasil. Funcionam como instrumentos linguísticos. Segundo Auroux (1992), os instrumentos linguísticos são compreendidos como produtos do processo de gramatização, entendida como "o processo que conduz a língua na base de duas tecnologias ainda hoje os pilares de nosso saber metalinguístico: a gramática e o dicionário" (idem, pág 65). Os glossários, ampliando a noção proposta por Auroux, também cumprem este papel.

Ainda sobre instrumentos linguísticos, Nunes (2008a) nos diz que "constroem uma unidade para a língua, [...] e a produção dessa unidade não é jamais neutra, ela é condicionada pelo funcionamento da representação linguística, que é também uma representação política" (ibidem, p. 120). Tomemos, como exemplo, a publicação de $O$ Guarani, inicialmente em folhetim no Diário do Rio de Janeiro e lançado em livro em 1857. Coincidentemente, tal ano corresponde aos 100 anos da proibição da língua tupi em solo brasileiro. Não é o caso de traçar uma relação direta entre tais acontecimentos, mas não se pode deixar de considerar que o século XIX está envolto em questões linguísticas, atreladas à formação de um Estado nacional independente, e a trilogia indianista de José de Alencar não é indiferente a tais questões. São extensas e inúmeras as notas sobre língua e formas de vida indígenas, como se pode observar em parte do arquivo construído e exposto na terceira parte deste artigo.

É preciso lembrar que, neste momento de descolonização linguística, a produção de saberes metalinguísticos se intensifica. Há uma produção de 
uma memória documental, entendida como "um espaço estratificado de formulações" (NUNES, 2008, p. 86), em que "os estudiosos da linguagem no século XIX trabalham essa memória visando à construção de uma história do Brasil, na qual se interpretam os textos dos missionários em vista da construção de uma imagem do Tupi Antigo como língua originária romantizada, argumento para uma identidade nacional" (idem, pág. 86). Os dicionários produzidos aqui serviam inicialmente para complementar os dicionários portugueses, mas, ao final do século XIX, os dicionários de brasileirismos começam a ser elaborados com o objetivo de trazer à luz o léxico brasileiro. É neste cenário que se inscrevem as abundantes notas que Alencar insere em seus romances. Elas fazem parte do gesto de dar a conhecer sobre o Brasil e de servir à literatura. Observe-se o fragmento abaixo retirado do prefácio da $1^{\mathrm{a}}$ edição impressa de $\mathrm{O}$ Guarani:

As notas que vâo no fim explicarão algumas cousas que muitos não conhecem, por serem especialissimas ao interior do Brasil; ahi verá o leitor que a imaginação não fez mais do que dar algum colorido a costumes nacionaes, que podem se tornar uma fonte de poesia para a nossa literatura. (ALENCAR, O Guarani, 1857) ${ }^{4}$

Em poucas palavras, elas servem à formação de nação e de sujeitos nacionais. E servem ainda à formação da língua nacional, como apontamos anteriormente, como nos lembra Nunes (2002, p. 111) - "A literatura teve um papel importante na produção brasileira a partir da elaboração de léxicos anexos a romances, como em Diva de José de Alencar (1865) ${ }^{5 "}$ - , e como a leitura dos verbetes nos permitem constatar.

4 Em todos os verbetes foram preservadas as grafias originais.

5 No caso, O Guarani antecede Diva. Há diferenças significativas entre os dois romances no que diz respeitos ás notas. Diva se concentra no ambiente urbano e aí se encontram neologismos pelo autor ao lado de uma acirrada discussão sobre língua (Medeiros, 2017 ; 2019) 
Indo adiante, as notas de Alencar nos mostram a historicidade da língua assim como o seu processo de institucionalização no Brasil, o que se pode observar quando, em Iracema, por exemplo, o verbete trata da formação de palavras e da etimologia ou quando se discute a legitimação de determinadas ortografias em detrimento de outras. Veja-se o verbete Marangab:

Marangab: A serra da Maranguape distante cinco léguas da capital, e notável pela sua fertilidade e formosura, o nome indígena compõe-se de maran guerrear e coaub sabedor; maran, talvez seja abreviação de maramonhang, fazer guerra, se não é, como eu penso, o substantivo simples guerrear, de que se fez o verbo composto. O Dr. Martius traz ethmologia diversa. Mara, arvore, angai, de nenhuma maneira, guabe, comer. Esta ethmologia nem me parece própria ao objecto que e uma serra, nem conforme com os preceitos da língua. (ALENCAR, Iracema, 1865)

Neste trecho podemos constatar como a discussão sobre a etimologia da palavra se faz presente. Alencar aí se configura como um legislador da língua, na medida em que mostra diversas fontes, elaborando um grande trabalho de pesquisa e averiguação das mesmas, para, ao final, emitir seu parecer sobre qual seria a melhor grafia e origem. Para justificar sua posição, afirma que a etimologia de Dr. Martius não está em conformidade com "os preceitos da língua”. Mais uma vez, se torna visível o fato de que o glossário funciona como um campo de disputas sobre língua nacional, com seus acréscimos advindo de outras línguas e com a relação entre elas. Línguas outras, vale lembrar, descritas à luz de parâmetros da língua portuguesa, num processo de exogramatização ${ }^{6}$. Ler tais verbetes corroboram para o argumento de que

6 Conforme Auroux, o processo de gramatização "corresponde a uma transferência de tecnologia de uma língua para outras línguas, transferência que não é, claro, nunca totalmente independente de uma transferência cultural mais ampla" (AUROUX, 1992, p 74). Tal transferência pode se dar por endotransferência, quando os locutores são nativos; e por exotransferência, quando não o são, caso da produção de Alencar ao descrever o léxico em suas notas.

Confluência. Rio de Janeiro: Liceu Literário Português, n. 61, p. 66-98, jul.-dez. 2021 
a disponibilização desse glossário permitirá a ampliação do entendimento da historicidade da língua em solo brasileiro, atrelada a produção de saberes metalinguísticos no século XIX.

A leitura dos verbetes nos permitem ainda mais. Conforme Auroux (1992), o saber tem espessura temporal:

Todo conhecimento é uma realidade histórica, sendo que seu modo de existência real não é a atemporalidade ideal da ordem lógica do desfraldamento do verdadeiro, mas a temporalidade ramificada da constituição cotidiana do saber. Porque é limitado, o ato de saber possui, por definição, uma espessura temporal, um horizonte de retrospecção, assim como um horizonte de projeção. O saber (as instâncias que o fazem trabalhar) não destrói seu passado como se crê erroneamente com freqüência, ele o organiza, o escolhe, o esquece, o imagina, o idealiza do mesmo modo que antecipa seu futuro sonhando-o enquanto o constrói. Sem memória e sem projeto, simplesmente não há saber. (AUROUX, 1992, p. 11-12)

O glossário que as notas compõem nos possibilita, na constituição do saber linguístico, perceber essa temporalidade ramificada e descortinar de imediato um horizonte de retrospeção que nele se inscreve em seus verbetes com sua referenciação e ir em busca de seus horizontes de projeção. Dessa forma, há tanto uma memória quanto uma atualização dessa memória, projetando-a para o futuro. Observem-se as referências nos dois verbetes de Iracema.

Ibyapaba: Grande serra que se prolonga ao norte da província e a extrema com Piauhy. Significa terra aparada. O Dr. Martius em seu glossario lhe attribue outra athmologia. Iby -terra - e pabe - tudo. A primeira porém tem a authoridade de Vieira. (ALENCAR, Iracema, 1865 , grifos nossos)

Pocema: grande alarido que faziao os selvagens nas occasiões solemnes como em começo de batalha, ou nas expansões da alegria; é palavra adoptada ja na língua portugueza e inserida no diccionario de Moraes. Vem de pomão e cemo clamar; clamor das mãos, porque os 
selvagens acompanhavão o vozear com o bater das palmas e das armas. (ALENCAR, Iracema, 1865, grifo nosso)

Em Ibyapaba, é possível notar o espaço de disputa em que a língua está inserida estabelecido através do confronto entre definições de dois autores Dr. Martius e Vieira. Embora o mesmo verbete se encontre nas duas fontes, a autoridade sobre ele advém de Vieira. Já com Pocema, ficamos sabendo que se trata de palavra de língua indígena já adotada na língua portuguesa, ou seja, como já constando de um dos mais importantes dicionários do século XIX: o dicionário de Moraes. Nessas e em outras notas, com suas referências e citações, descortinamos um horizonte de retropecção. Com efeito, nas notas nesses romances, assim como em Ubirajara, encontra-se uma variedade de autores citados: de viajantes e expedicionários em terras brasileiras a escritores, historiadores, filólogos e lexicógrafos. Observe-se o verbete cipós:

Cipós: Diz Gabriel Soares: — "Deo a natureza no Brasil, por entre os arvoredos, umas cordas muito rijas, muitas que nascem aos pés das arvores e atrepão por ellas acima, a que chamão cipós, com que os indios atão a madeira de suas casas e os brancos que não podem mais. Nestes mesmos mattos se crião outras cordas mais delgadas e primas a que os indios chamavão "timbós », que sao mais rijas que os cipós acima." (ALENCAR, O Guarani, 1857).

Nessa nota, por exemplo, a definição se resume a um fragmento advindo de Gabriel Soares a respeito desse elemento da flora brasileira. E nela lemos as mais diversas informações sobre a natureza dos cipós. "Deo a natureza no Brasil" faz significar o solo brasieliro como particular, como único. Também se relata onde crescem os cipós, seu formato e durabilidade: "cordas muito rijas". Seu uso serve para atar a madeira das casas devido a sua rigidez e facilidade de utilização, uma vez que é parecido com uma corda. Em poucas palavras, por essas notas circulam saberes e costumes dos povos indígenas, assim como conhecimentos sobre a fauna e a flora brasileira. 
Em curarê, outras são as observações:

Curarê "Le bororé dont le reverend père Gumilha a donnè la description dans son Orenoco illustrado parait être exaetement le même dont l'Abbé Gilly parle dans son histoire de l'Amerique et q'on designe aujourd'hui par le nom de Curarê. Suivant Mr. Humboldt est un striehnos, et il ne faut pas le confondre avee le tucunas composé toxicue* dont parle Mr. de La Condamine dans la relation de son voyage aux Amazones. $>>$ DR. SIGAUD, - Du Climat et des Maladies du Bresil." (ALENCAR, $O$ Guarani, 1857) ${ }^{7}$

Trata-se de um verbete escrito em francês, o que nos traz pistas importantes sobre o leitor e sobre o alcance da literatura de José de Alencar. Em um país com um alto índice de analfabetismo, quem poderia ler este tipo de nota escrita em uma língua estrangeira? Para Abreu (2011), nos romances de Alencar encontram-se dois universos narrativos: aquele do enredo e aquele das notas. No primeiro, teríamos um narrador contemplativo; no outro, um narrador histórico. Diremos que sobre o segundo incide a posição lexicógrafo (MEDEIROS, 2017). São posições que implicam, por vezes, leitores distintos.

Ainda sobre curarê, somos levados a outros saberes, no verbete seguinte:

Em algumas horas: Sobre a violencia do Curaré diz ainda o Dr. Sigaud o seguinte : "En 1830 le president C. J. de Nyemer aporta du Pará à Rio de Janeiro une petite portion de Curaré qu'on fit prende à petite dozes á divers animaux qui tous ont suceombeén pen d'heures dans des convulsions violentes. Le docteur Lacerda qui a long temps pratique au Pará et au Maranhão a fait, dit-on, d'importantes recherehes sur les

7 "O curarê que o Reverendo Padre Gumilha descreveu em seu Orenoco Illustrado parecer ser exatamente o mesmo que l'Abbé fala em sua Historie de L'Amerique e que designamos atualmente pelo nome de Curarê. De acordo com Mr. Humboldt, trata-se de um striehnos e não deve ser confundido com o composto tóxico dos tucunas que fala Mr. de La Condamine em seu relato de sua viagem ao Amazonas" (tradução nossa).

Confluência. Rio de Janeiro: Liceu Literário Português, n. 61, p. 66-98, jul.-dez. 2021 
poisons indiens encore inédites ; le Curaré est de son aven un poison violent causant d'abordun ètat tetanique, ensuite une torpeur generale qui precede la mort." (ALENCAR, O Guarani, 1857) ${ }^{8}$

Como é possível observar, essa nota porta uma reflexão sobre aspectos médicos e psicóticos que o veneno causa. Não somente, aí se trata também da posologia e da duração dos efeitos no organismo. Com a citação ficamos sabendo que há pesquisas sobre as porções indígenas que ainda são inéditas e que poderiam ajudar no entendimento da atuação do Curarê. As referências e citações nos mostram ainda a circulação desses saberes em lugares outros. Com efeito, com as notas abre-se uma janela que nos permite descortinar um horizonte de que questões e reflexões sobre o século XIX, um horizonte rico para conhecimentos diversos e sobretudo para pesquisas linguísticas.

\section{Da composição do arquivo e do arquivo a conhecer}

$\mathrm{O}$ arquivo que se pode ler a seguir conta com 202 notas dos dois romances selecionados, a saber, O Guarani e Iracema. No primeiro se encontram 74 notas e no segundo 128. As notas de rodapé na primeira edição dos livros de O Guarani e Iracema se situam ao final do romance. O Guarani, por se tratar de um livro dividido em quatro partes, as notas aparecem ao final de cada partição. O trabalho aqui empreendido de construção de um arquivo de língua, ancorado na articulação entre os campos teóricos da Análise do Discurso e da História das Ideias Linguísticas, permite que se mergulhe neste universo linguístico oitocentista e que se possa, a partir dele, tecer análises outras e dar curso a futuras pesquisas.

8 "Em 1830 o presidente C.J. de Nyemer aporta do Para ao Rio de Janeiro uma pequena porção do Curarê que foram bebidas em pequenas doses por diversos animais e todos sucumbiram em poucas horas em convulsões violentas. O Dr. Lacerda, que há muito tempo pratica no Pará e no Maranhão, fez importantes pesquisas sobres os peixes indígenas ainda inéditos; o Curaré é um veneno violento que causa primeiro um estado tetânico e, consequentemente, um torpor geral que precede a morte" (tradução nossa).

Confluência. Rio de Janeiro: Liceu Literário Português, n. 61, p. 66-98, jul.-dez. 2021 
Ainda sobre sua montagem, é preciso explicar que foi articulado da seguinte forma: os verbetes foram (i) listados de acordo com seu aparecimento no livro; (ii) transcritos conforme se apresentam, isto é, mantendo a grafia original; (iii) indicadas as partes do livro. Essa versão está disponibilizada em https://gal.hypotheses.org/arquivos-das-margens, onde é possível realizar buscas na tabela feita utilizando o Excel. Lá se encontra também o fragmento do romance de onde sai a nota. Para o presente artigo, optamos por trazer verbete e definições. Para a composição do arquivo, trabalhamos com as primeiras edições que foram obtidas com Biblioteca Brasiliana Guita e José Mindlin (disponível em: https://digital.bbm.usp.br/handle/bbm-ext/1) ${ }^{9}$.

Por fim, cabe salientar que se trata de uma edição exaustiva e inédita de suas notas, que denunciam o criterioso estudo sobre línguas por este grande escritor oitocentista. É hora de ir ao arquivo.

Tabela 1. Arquivo das notas de $O$ GUARANI (ALENCAR, 1857) ${ }^{10,11}$

\begin{tabular}{|l|l|}
\hline \multicolumn{1}{|c|}{ Parte I } \\
\hline Guarany & $\begin{array}{l}\text { O titulo qua damos a este romance significa o indigena brasileiro. Na } \\
\text { occasião da descoberta, o Brasil era povoado por nacões pertencentes á } \\
\text { uma grande raça, que conquistára o paiz havia muito tempo, e expulsára } \\
\text { os dominadores. Os chronistas ordinariamente designavão esta raça pelo } \\
\text { nome-Tupi; mas esta denominação não era usada senão por algumas } \\
\text { nações. Entendemos que a melhor designação que se lhe polia dar era a da } \\
\text { lingua geral que fallavão, e que naturalmente lembrava o nome primitivo } \\
\text { ria grande nação, antes de sua divisão. }\end{array}$ \\
\hline O Paquequer & $\begin{array}{l}\text { Para se conhecer a exactidão dessa descripção do rio Paquequer naquella } \\
\text { época, lêa-se B. da Silva Lisboa-Annaes do Rio de Janeiro } 1^{\circ} \text { tomo } \\
\text { pag. 162. Hoje as grandes plantações de café transformárão Inteiramente } \\
\text { aquelles lugares outr'ora virgens e desertos. }\end{array}$ \\
\hline
\end{tabular}

continua

9 Uma observação: edições mais recentes de ambos os romances suprimem alguns verbetes.

10 Edição disponível na Biblioteca Brasiliana: https://digital.bbm.usp.br/handle/bbm/4655

Confluência. Rio de Janeiro: Liceu Literário Português, n. 61, p. 66-98, jul.-dez. 2021 


\begin{tabular}{|c|c|}
\hline Brasão d'armas & $\begin{array}{l}\text { Este brasão da casa dos Marizes ê histórico ; nos mesmos Annaes do Rio de } \\
\text { Janeiro tomo } 1^{\circ} \text { pag. } 329 \text { acha-se a sua descripção. }\end{array}$ \\
\hline $\begin{array}{l}\text { D. Anto } \\
\text { Mariz }\end{array}$ & $\begin{array}{l}\text { Este personagem é histórico, assim como os factos que se referem ao seu } \\
\text { passado, antes da época em que começa o romance. Nos Annaes do Rio de } \\
\text { Janeiro tomo. } 1^{\circ} \text { pag. } 328 \text { lê-se uma breve noticia sobre sua vida. }\end{array}$ \\
\hline $\begin{array}{l}\text { D. Pedro da } \\
\text { Cunha }\end{array}$ & $\begin{array}{l}\text { Deste projecto de transportar ao Brasil a corôa portugueza, falla o Sr. } \\
\text { Warnhagen na sua Historia do Brasil. }\end{array}$ \\
\hline Aventureiros & $\begin{array}{l}\text { O costume que tinhão os capitães daquelle tempo de manterem uma banda } \\
\text { de aventureiros ás suas ordens, é referido por todos os chronistas. Esse } \\
\text { costume tinha o quer que seja dos usos da média-idade, e a necessidade o } \\
\text { fez reviver em nosso paiz onde faltavão tropas regulares para as conquistas } \\
\text { e explorações. }\end{array}$ \\
\hline $\begin{array}{l}\text { D. Diogo de } \\
\text { Mariz }\end{array}$ & $\begin{array}{l}\text { Este personagem tambem é histórico. Em } 1607 \text { era provedor da alfandega } \\
\text { do Rio de Janeiro, cargo que tinha servido seu pai alguns annos antes. }\end{array}$ \\
\hline Um i & $\begin{array}{l}\text { O typo que descrevemos é inteiramente copiado das observações que } \\
\text { se encontrão em todos os chronistas. Em um ponto porém varião os } \\
\text { escriptores; uns dão aos nossos selvagens uma estatura* abaixo da regular } \\
\text {; outros uma estatua alta (sic). Neste ponto preferi guiar-me por Gabriel } \\
\text { Soares que escreveo em 1580, e que nesse tempo devia conhecer a raça } \\
\text { indígena em todo o seu vigor, e não degenerada como se tornou depois. }\end{array}$ \\
\hline For & $\begin{array}{l}\text { Esta maneira de caçar uma onça que a muitos parecerá extraordinaria, é } \\
\text { referida por Ayres do Casal. Ainda hoje no interior ha sertanejos que cação } \\
\text { deste modo, e sem o menor risco ou difficuldade, tão habituados já estão. }\end{array}$ \\
\hline Ticum & $\begin{array}{l}\text { O ticum é uma palmeira de cujos filamentos os indios usavão como os } \\
\text { europeos do Snho. Della se servião para suas redes de pesca, para cordas de } \\
\text { arco e outros misteres; o fio preparado por elles com a resina de almecega } \\
\text { era fortissimo. }\end{array}$ \\
\hline Biribá & $\begin{array}{l}\text { O biribá era a arvore com qne os indígenas tiravão fogo por meio do } \\
\text { attrito, roçaudo fortemente um fragmento de encontro ao outro. B. da S. } \\
\text { Lisboa.-Annaes. }\end{array}$ \\
\hline Gardenia & $\begin{array}{l}\text { E' o nome scientifico que Fr. Velloso na sua Flora Fluminensis dá á açucena } \\
\text { silvestre; nos nossos campos encoutra-se essa flor dé* varias côres; a mais } \\
\text { commum é a branca e escarlate. }\end{array}$ \\
\hline
\end{tabular}




\begin{tabular}{|c|c|}
\hline Pery & $\begin{array}{l}\text { E' uma palavra da lingua guarany que significa - junco silvestre. Todos } \\
\text { os nomes dos nossos indígenas erão* ordinariamente de animaes ou de } \\
\text { arvores, como succede com todos os povos selvagens. }\end{array}$ \\
\hline Oleo & $\begin{array}{l}\text { E' uma das arvores mais elevadas de nossas florestas; cresce a mais de cem } \\
\text { palmos, e o tronco chega á uma extraordinária grossura. }\end{array}$ \\
\hline Hirara & $\begin{array}{l}\text { Especie de gato selvagem, indigena do Brasil: em Ayires do Casal, } \\
\text { Topographia Brasilica se encontra* a descripção deste animal, assim como } \\
\text { de outos de que fallamos. }\end{array}$ \\
\hline Soffer & $\begin{array}{l}\text { E' um lindo passaro do Brasil, côr de ouro, com os encontros de um negro } \\
\text { brilhante. O seu canto doce imita a palavra soffrer, razão por que os } \\
\text { primeiros colonos lhe derão esse nome. }\end{array}$ \\
\hline Cecy & $\begin{array}{l}\text { E' um verbo da lingua guarany que significa magoar, doer. roucas palavras } \\
\text { se encoutrão na nossa lingua mais suaves e melodiosas do que esta. }\end{array}$ \\
\hline Sapucaia & $\begin{array}{l}\text { Arvore de alta grandeza, que dá um fructo do tamanho e da confeição de } \\
\text { um côco. }\end{array}$ \\
\hline Pequiá & $\begin{array}{l}\text { Arvore de mais de cem palmos de altura, que tem uma pequena flor de } \\
\text { brilhante escarlate ; floresce nos mezes de setembro e outubro. }\end{array}$ \\
\hline O cactus & $\begin{array}{l}\text { Temos differentes especies de cactus ; os mais lindos são o branco, o rosa } \\
\text { e o amarello, a que os indígenas chamavão urumbeba. Todos elles abrem á } \\
\text { meia noite e fechão ao despontar do sol. }\end{array}$ \\
\hline Graciola & $\begin{array}{l}\text { E' o nome scientifico que Fr. Velloso na sua Flora Fluminense dá á pequena } \\
\text { flor azul de um arbusto indigena. }\end{array}$ \\
\hline Malvalisco & $\begin{array}{l}\text { Nome que Saint-Hilaire deo á uma espécie de malva indigena brasileira, } \\
\text { cuja flor é escarlate. }\end{array}$ \\
\hline Viuvinha & $\begin{array}{l}\text { Pequeno passaro negro que canta ao amanhecer; dizem ser o primeiro que } \\
\text { saúda o nascimento do dia. }\end{array}$ \\
\hline Jasmineiro & $\begin{array}{l}\text { Ha uma especie de jasmineiro indigena do Brasil; assim o dizem os dous } \\
\text { botânicos que citámos acima. }\end{array}$ \\
\hline Bem te-vi & $\begin{array}{l}\text { O canto deste passarinho é uma das curiosidades da nossa terra, que mais } \\
\text { admirou aos Portuguezes ; muitos chronistas fallão disto. E com effeito a } \\
\text { imitação das palavras é a mais perfeita possível. }\end{array}$ \\
\hline Colhereira & $\begin{array}{l}\text { E' uma das aves aquaticas mais lindas do Brasil ; suas pennas são de um } \\
\text { bello côr de rosa. }\end{array}$ \\
\hline
\end{tabular}




\begin{tabular}{|c|c|}
\hline O cão & $\begin{array}{l}\text { Diz o Sr. Warnagen na sua historia do Brasil que o cão era o companheiro } \\
\text { constante do nosso indígena, ainda mais do que do europeu. }\end{array}$ \\
\hline Cabuiba & $\begin{array}{l}\text { A cabuiba ou cabureiba-Balsamum Peruvianum de Pison, cabuiba iba } \\
\text { Marcgrave e Miroxilem Cabriuva de outros naturalistas- é uma arvore } \\
\text { das nossas mattas de mais de cem palmos, e a que vulgarmente se chama } \\
\text { arvore do balsamo. Destilla um licor louro de um cheiro agradavel, que } \\
\text { dizem milagroso para cura de feridas frescas. (Gabriel Soares, B. Lisboa } \\
\text { e Ayres de Casal). }\end{array}$ \\
\hline Formigueiro & $\begin{array}{l}\text { No sertão encontrão-se frequentemente essas escavações subterrâneas, } \\
\text { feitas por uma formiga, a que os índios chamárão Taciahy. }\end{array}$ \\
\hline Garcia Ferreiro & $\begin{array}{l}\text { Garcia Ferreira foi provido no officio de tabellíão do Rio de Janeiro por } \\
\text { Salvador Corrêa de Sá, em } 15 \text { de fevereiro de 1588. (B. da Silva Lisboa). }\end{array}$ \\
\hline Roberto Dias & $\begin{array}{l}\text { Roberto Dias offereceo a Felippe II o segredo de uma grande mina de prata, } \\
\text { descoberta por elle nos sertões de Jacobina, provincia da Bahia ; pedia em } \\
\text { troca o titulo de marquez das Minas, que não lhe foi dado. Essas minas falsas } \\
\text { ou verdadeiras nunca se descobrirão. Roberto morreo na Hespanha pobre e } \\
\text { desgraçado, recusando revelar o segredo das minas. (B. da S. Lisboa). }\end{array}$ \\
\hline \multicolumn{2}{|r|}{ Parte II } \\
\hline $\begin{array}{l}\text { Convento do } \\
\text { Carmo }\end{array}$ & $\begin{array}{l}\text { "Logo que os carmelitas se estabelecerão em Santos, pela doação de José } \\
\text { Adorno, de } 1589 \text {, se passou ao Rio de Janeiro o padre frei Pedro, para } \\
\text { fundar aqui o convento do Carmo. Supposto não conste com certeza o anno } \\
\text { da fundação, é indisputavel todavia que fora entre } 1589 \text { e } 1590 \text {, pois que já } \\
\text { estava aquelle feito em } 1595 \text {. Corria por tradicçao geralmente ter sido o seo } \\
\text { começo em } 1590 . " \text { (B. da S. Lisboa, tom. } 7^{\circ} \text {, cap. } 2^{\circ}, \S 6 \text {.) }\end{array}$ \\
\hline Loredano & $\begin{array}{l}\text { Esta creação não tem nada de inverosimil. Ao contrario, o facto dessa } \\
\text { immoralidade da ordem do Carmo, naquelle tempo, é não só natural, } \\
\text { mas real e acontecido. No autor acima citado lê-se um breve do Nuncio } \\
\text { Apostolico, Vicente Ranuzio, nomeando ao bispo do Rio de Janeiro } \\
\text { visitador e reformador dos carmelitas, por causa dos muitos abusos } \\
\text { commettidos nessa ordem. (B. da S. Lisboa, tom. } 7^{\circ} \text {, pag. 102.) }\end{array}$ \\
\hline $\begin{array}{l}\text { Saio de } \\
\text { algodão }\end{array}$ & $\begin{array}{l}\text { Referem os chronistas que muitas tribus indias fiavão o algodão para vestir- } \\
\text { se, fazer redes e outros objectos. No « Diccionario da Língua Brasilica » } \\
\text { encontramos a palavra « guarina » significando « camizas, gibão. » Isto } \\
\text { nos autorisou a apresentar um selvagem assim trajado, sem faltar em nada } \\
\text { á verdade ; devendo-se notar que os Goytacazes erão uma das nações mais } \\
\text { industriosas. }\end{array}$ \\
\hline
\end{tabular}




\begin{tabular}{|c|c|}
\hline $\begin{array}{l}\text { Arvores de } \\
\text { ouro }\end{array}$ & $\begin{array}{l}\text { A sapucaia perde a folha no tempo da florescencia, e cobre- } \\
\text { se de tanta flôr amarella que não se vê nem tronco, nem galhos } \\
\text {; o mesmo succede á embaiba ao páo* d'arco e outras arvores. } \\
\text { (G. Soares. - Roteiro do Brasil e B. da S. Lisboa.-Annaes.) } \\
\text { Sendo a época da florescência dessas arvores em setembro, a phrase } \\
\text { figurada do indio traduz-se da seguinte maneira: - « Era o mez de } \\
\text { setembro.» }\end{array}$ \\
\hline O mais forte & $\begin{array}{l}\text { E' sabido que entre as nossas tribus, o chefe era sempre aquelle que tinha } \\
\text { maior reputação de valor e fortaleza. O principio de hereditariedade, se } \\
\text { algumas vezes regulava a successão do mando, era ephemero. }\end{array}$ \\
\hline $\begin{array}{l}\text { Taba dos } \\
\text { brancos }\end{array}$ & $\begin{array}{l}\text { Allude-se á colônia da Victoria, hoje capital da província do Espirito Santo, } \\
\text { que foi duas vezes arrancada pelos Goytacazes, Tupininquins. E'um desses } \\
\text { combates, que o indio conta de passagem. }\end{array}$ \\
\hline Casa da Cruz & $\begin{array}{l}\text { E' a expressão pela qual um selvagem poderia exprimir « a igreja. » Poderia } \\
\text { dizer casa de Tupã ; mas seria confundir a sua religião com a dos seos } \\
\text { inimigos. }\end{array}$ \\
\hline $\begin{array}{l}\text { Senhora dos } \\
\text { brancos }\end{array}$ & $\begin{array}{l}\text { Pela discripçao que segue conhece-se* que o selvagem vio na igreja, na } \\
\text { occasião do incêndio que devorou a villa da Victoria, uma imagem de } \\
\text { Nossa Senhora, que o impressionou vivamente. }\end{array}$ \\
\hline $\begin{array}{l}\text { A estrella } \\
\text { grande }\end{array}$ & $\begin{array}{l}\text { O que dizem alguns chronistas, a respeito da ignorância absoluta dos } \\
\text { indígenas sobre a astronomia, me parece* inexacto. Os Guaranis tinhão } \\
\text { esses conhecimentos rudes, filhos da observaçao. Chamavão a estrella - } \\
\text { «jacy-tata » - fogo da lua ; suppunhão pois que a lua é que transmittia } \\
\text { a luz ás estrellas. Conhecião as quatro phazes do lua:-a luanova «jacy- } \\
\text { peçaçu»; o quarto crescente «jacy-jemorotuçu »; a lua cheia «jacy- } \\
\text { çabaoçu;» e o quarto minguante «jacy-jearoca. » Dividião o anno em duas } \\
\text { estações : a estação do sol « coaracyara » e a estação da chuva « amara-ara } \\
\text {; sao as mesmas que hoje conhecemos, e as únicas que realmente existem } \\
\text { no Brasil. Muitas outras observações podíamos fazer, que omittimos para } \\
\text { evitar prolixidade. }\end{array}$ \\
\hline O cajueiro & $\begin{array}{l}\text { Esta imagem é a mais verdadeira possível: no tempo da muda das folhas, } \\
\text { o tronco dessa arvore verte uma resina de que os índios fazião muito uso e } \\
\text { que ainda hoje serve no norte para substituir a gomma-arabica. }\end{array}$ \\
\hline O sabiá cantou & $\begin{array}{l}\text { Esse tempo que o indio descreve, e que se poderia chammar a nossa } \\
\text { primavera, é o tempo da quaresma; tudo reverdece; os mattos cobrem-se } \\
\text { de flores; os passarinhos cantão seos innocentes amores. }\end{array}$ \\
\hline
\end{tabular}




\begin{tabular}{|c|c|}
\hline Grande rio & $\begin{array}{l}\text { Esta palavra é relativa : todas as nações chamavão assim o maior rio que } \\
\text { havia no territorio que ellas conhecião, e é por isso que se encontrão tantos } \\
\text { «rios grandes» nos nomes dos rios do nosso paiz. Para os Goytacazes o } \\
\text { Rio-Grande era o Parahyba. }\end{array}$ \\
\hline Gavião & $\begin{array}{l}\text { O gavião é a nossa aguia, é o passaro mais altaneiro e que tem o vôo mais } \\
\text { rapido. Muitos escriptores o compárão ao falcão europeu. }\end{array}$ \\
\hline $\begin{array}{l}\text { A nação } \\
\text { goytacaz }\end{array}$ & $\begin{array}{l}\text { Esses factos lêem-se em qualquer* dos escriptores que se tenhão occupado } \\
\text { dos primeiros tempos coloniaes do Brasil, e especialmente em G. Soares, } \\
\text { que foi contemporaneo delles. }\end{array}$ \\
\hline Colibri & $\begin{array}{l}\text { A belleza desse pássaro é uma maravilha da natureza brasileira ; } \\
\text { conhecem-se cerca de mil espécies, e os naturalistas ainda não puderão } \\
\text { classifical-as todas. }\end{array}$ \\
\hline Um canto & $\begin{array}{l}\text { Os indios erão muito affeiçoados á musica, e tinhão diversos cantos como } \\
\text { refere Lamartinière. Tendo de escrever uma imitação desses cantos, adoptei } \\
\text { uma certa harmonia de períodos, uma certa cadência de phrases e mesmo } \\
\text { de entonação, que devia para esses povos incultos supprir a metrificação } \\
\text { da poesia. Não sabemos se fomos felizes no pensamento. }\end{array}$ \\
\hline Cipós & $\begin{array}{l}\text { Diz Gabriel Soares: "Deo a natureza no Brasil, por entre os arvoredos, } \\
\text { umas cordas muito rijas, muitas que nascem aos pés das arvores e } \\
\text { atrepão por ellas acima, a que chamão cipós, com que os indios atão } \\
\text { a madeira de suas casas e os brancos que não podem mais. Nestes } \\
\text { mesmos mattos se crião outras cordas mais delgadas e primas a } \\
\text { que os indios chamavão " timbós ", que sao mais rijas que os cipós } \\
\text { acima". } \\
\text { A quantidade"infinita"de cipós é uma das originalidades das florestas do } \\
\text { Brasil, e admirou os naturalistas estrangeiros que o visitárão." }\end{array}$ \\
\hline Candeia & $\begin{array}{l}\text { Diz o mesmo autor: "Ha uma arvore meã que se chama « ibiriba » a qual } \\
\text { os indios fazem em fios para fachos, com que vão mariscar e para andarem } \\
\text { de noute ; e ainda que seja verde, cortada daquella hora, pega o fogo nella } \\
\text { como em alcatrão, e não apaga o vento os fachos della ; e em casa servem- } \\
\text { se os índios de achas dessa madeira, como de candêas*." }\end{array}$ \\
\hline Cauam & $\begin{array}{l}\text { O « cauam» ou a «c auam'» é"um passaro que devora as cobras, pelo que } \\
\text { ellas fogemdelle. Os índios, segundo affirma Ayres do Casal, imitavão o } \\
\text { seo canto, quando andavão á noite pelo matto, e assim preservavão-se de } \\
\text { serem mordidos. }\end{array}$ \\
\hline
\end{tabular}




\begin{tabular}{|c|c|}
\hline $\begin{array}{l}\text { Setta por } \\
\text { elevação }\end{array}$ & $\begin{array}{l}\text { A destreza e a habilidade com que os indios atiravão a setta era tal, que os } \\
\text { europeus a admiravão. Para atirarem por elevação, deitavão-se, seguravão } \\
\text { o arco com os dous dedos dos pés e lançavão ao ar a setta, que, subindo, } \\
\text { descrevia uma parabola e ia cahir no alvo. Ainda ha pouco tempo, no Pará se } \\
\text { vião, nas aldêas de indios já cathequisados, pareos deste jogo, em que o alvo } \\
\text { era um tronco de Bananeira decepado. O tenente Pimentel, filho do presidente } \\
\text { de Matto-Grosso, foi assassinado na viagem pelos Índios deste modo, e } \\
\text { cavalgando no meio de muitos cavalleiros. Nenhum foi ferido; e todas as settas } \\
\text { abatêrão-se* sobre o moço de quem os selvagens se querião vingar. }\end{array}$ \\
\hline \multicolumn{2}{|r|}{ Parte III } \\
\hline $\begin{array}{l}\text { Crispim } \\
\text { Tenreiro }\end{array}$ & $\begin{array}{l}\text { Foi um dos fundadores do Rio de Janeiro ; era casado com D. Isabel Mariz, } \\
\text { mulher de D. Antonio. }\end{array}$ \\
\hline Aimorés & $\begin{array}{l}\text { Era uma tribu de selvagens ainda mais barbaros do que os tupis ; } \\
\text { assemelhavão-se á verdadeiras feras. Resava a tradicção indígena que } \\
\text { provinhãode uma tribu daraça tapuia que em virtude de guerras se entranhára } \\
\text { pelos sertões, e ahi separada das outras perdera os hábitos, os costumes, e } \\
\text { até a lingua primitiva. A discripção que fazemos destes selvagens na quarta } \\
\text { parte dispensa-nos de reproduzir aqui, o que lá dissemos. }\end{array}$ \\
\hline Mussuranas & $\begin{array}{l}\text { "« Os contrarios que os Tupinambás captivão na guerra ou de outra } \\
\text { maneira, mettem-nos em prisões, as quaes sao cordas de algodão grossas, } \\
\text { que para isso tem muito louçãas (sic) a que chamão mussuranas.-G. S. DE } \\
\text { SOUZA.--Roteiro do Brasil." }\end{array}$ \\
\hline $\begin{array}{l}\text { Esposa do } \\
\text { Tumulo }\end{array}$ & $\begin{array}{l}\text { "« Dão á cada um prisioneiro por mulher a mais formosa moça que ha na } \\
\text { sua casa ; a qual moça tem o cuidado de o servir e dar-lhe o necessário para } \\
\text { comer e beber. »—G. SOARES DE SOUZA._- Roteiro do Brasil cap. 71." }\end{array}$ \\
\hline Cardo & $\begin{array}{l}\text { Cardo é o fructo da urumbeba e de outras palmas de espinhos de que ha } \\
\text { differentes éspcies ; é vermelho na casca, de polpa branca e sementes pretas. }\end{array}$ \\
\hline Corrixo & $\begin{array}{l}\text { Corrixo é um passarinho que tem o dom de arremedar a todos os outros. } \\
\text { "Temos o pássaro que entôa Por mil differentes modos, Porque elle } \\
\text { remeda a todos, Seu próprio nome é corrixo. " J. J. LISBOA. - Desc. } \\
\text { Curiosa. }\end{array}$ \\
\hline És livre & $\begin{array}{l}\text { "Mas também ha algumas que tomarão tamanho amor aos captivos que as } \\
\text { tomárão por mulher, que lhe derão muito geito para se acolherem e fugirem } \\
\text { das prisões que elles cortão com alguma ferramenta que ellas ás escondidas } \\
\text { lhe derão, etc. » - G. SOARES DE SOUZA. - Roteiro do Brasil, Cap. } 171 \text {. }\end{array}$ \\
\hline
\end{tabular}




\begin{tabular}{|c|c|}
\hline \multicolumn{2}{|r|}{ Parte IV } \\
\hline Sacrificio & $\begin{array}{l}\text { Os costumes dos Aymorés não eram inteiramente conhecidos, por causa } \\
\text { do afastamento em que sempre vivêrão dos colonos. Em algumas cousas } \\
\text { porém assemelhavão-se á raça tupy ; e é por isso que na descripção do } \\
\text { sacrifício aproveitamos o que dizem Simão de Vasconcellos e Lamartinière } \\
\text { a respeito dos Tupinambás e outras tribus mais ferozes. }\end{array}$ \\
\hline $\begin{array}{l}\text { A sua bella } \\
\text { lingua }\end{array}$ & $\begin{array}{l}\text { Tomei a liberdade de fazer que o velho chefe Aimoré fallasse o guarany; o } \\
\text { que aliás era muito natural. Fr. Santa Rita Durão, no seu poema Caramurú, } \\
\text { fez mais, porque attribuio a Paraguassú o conhecimento da lingua } \\
\text { portugueza, antes da chegada de Diogo Alvares. }\end{array}$ \\
\hline Veneno & $\begin{array}{l}\text { Os indigenas fabricavão diversos venenos, e a sua perfeição foi objecto de } \\
\text { admiração para os colonisadores. Humboldt, á vista de seus conhecimentos } \\
\text { toxicologicos, concluio que devia ter havido na America igualmente uma } \\
\text { grande civilisação, e que della havião os selvagens herdado esses usos. Os } \\
\text { principaes desses venenos erão o bororé e o uirari. }\end{array}$ \\
\hline Curarê & $\begin{array}{l}\text { "Le bororé dont le reverend père Gumilha a donnè la description dans son } \\
\text { Orenoco illustrado parait être exaetement le même dont l'Abbé Gilly parle } \\
\text { dans son histoire de l'Amerique et q'on designe aujourd'hui par le nom de } \\
\text { Curarê. Suivant Mr. Humboldt est un striehnos, et il ne faut pas le confondre } \\
\text { avee le tucunas composé toxicue* dont parle Mr. de La Condamine dans la } \\
\text { relation de son voyage aux Amazones. - DR. SIGAUD, - Du Climat et des } \\
\text { Maladies du Bresil." }\end{array}$ \\
\hline $\begin{array}{l}\text { Em algumas } \\
\text { horas }\end{array}$ & $\begin{array}{l}\text { Sobre a violencia do Curaré diz ainda o Dr. Sigaud o seguinte : } \\
\text { "En } 1830 \text { le president C. J. de Nyemer aporta du Pará à Rio de Janeiro une } \\
\text { petite portion de Curaré qu'on fit prende à petite dozes á divers animaux } \\
\text { qui tous ont suceombeén pen d'heures dans des convulsions violentes. Le } \\
\text { docteur Lacerda qui a long temps pratique au Pará et au Maranhão a fait, } \\
\text { dit-on, d'importantes recherehes sur les poisons indiens encore inédites ; le } \\
\text { Curaré est de son aven un poison violent causant d'abordun ètat tetanique, } \\
\text { ensuite une torpeur generale qui* precede la mort." }\end{array}$ \\
\hline $\begin{array}{l}\text { Se eevão no } \\
\text { sangue }\end{array}$ & $\begin{array}{l}\text { Sobre esse costume de antropophagia dos Aimorés leia-se Lamartiniére } \\
\text { - Diceionario geographieo - palavra Brasil. - G. SOARES Roteiro. - } \\
\text { WARNAGEM. - Historia do Brasil. }\end{array}$ \\
\hline Payas & $\begin{array}{l}\text { Outros dizem payés ou pagés ; erão uma especie de sacerdotes e magieos } \\
\text { dos indigenas. }\end{array}$ \\
\hline
\end{tabular}




\begin{tabular}{|c|c|}
\hline Contraveneno & $\begin{array}{l}\text { Segundo Humboldt, o assucar é um contraveneno do Curarê. Os indios } \\
\text { porém conhecião naturalmente contras muitos mais efficazes, e que hoje } \\
\text { ignora-se, do mesmo modo que o da cascavel. }\end{array}$ \\
\hline Setta hervada & $\begin{array}{l}\text { O Curarê tambem servia aos indios para hervarem as settas, e nesse caso } \\
\text { tinha preparação especial. Vid. Gunilha. - Orenoco Illustrado. }\end{array}$ \\
\hline Guanumbi & $\begin{array}{l}\text { Segundo uma tradicção dos indios o colibri que conhecião pelo nome de } \\
\text { guanumby levava e trazia as almas do outro mundo. }\end{array}$ \\
\hline Iris & $\begin{array}{l}\text { Diz Frei Velloso que a Flora Fluminense apresenta muitas variedades } \\
\text { desta flôr. }\end{array}$ \\
\hline $\begin{array}{l}\text { Arvores } \\
\text { aromaticas }\end{array}$ & $\begin{array}{l}\text { Diz G. Soares que na casa onde se queima o urathay recende o cheiro por } \\
\text { toda a rua. }\end{array}$ \\
\hline Igara & Significa em guarany canôa ; atyaty* é o nome que davão á gaivota. \\
\hline A inundação & $\begin{array}{l}\text { Geralmente sabe-se que o Parahyba é sujeito a grandes inundações por } \\
\text { causa da visinhança das serras que com as chuvas frequentes engrossão } \\
\text { os seus confluentes no inverno. Antigamente quando as matas não estavão } \\
\text { destruídas, essas inundações erão muito maiores do que actualmente. }\end{array}$ \\
\hline Tamandaré & $\begin{array}{l}\text { E' o nome do Noé indígena. A tradicção resava que na occasião do deluvio } \\
\text { elle escapara no olho de uma palmeira; e depois povoara a terra. A lenda } \\
\text { que conta Pery é uma imitacção. }\end{array}$ \\
\hline Palmeira & $\begin{array}{l}\text { Da possibilidade e verosimilhança do facto em que materialisamos a } \\
\text { tradicção indegena, fazendo Pery abrigar-se com Cecília no olho de } \\
\text { uma palmeira só duvidará quem não tiver visto essas arvores nos nossos } \\
\text { sertões, sobretudo quando nas enchentes os rios as arrancão da margem, e } \\
\text { as carregão na correnteza. }\end{array}$ \\
\hline
\end{tabular}

Confluência. Rio de Janeiro: Liceu Literário Português, n. 61, p. 66-98, jul.-dez. 2021 
Tabela 2. Arquivos das notas de IRACEMA (ALENCAR, 1865) ${ }^{11}$.

\begin{tabular}{|c|c|}
\hline $\begin{array}{l}\text { Onde canta a } \\
\text { jandaia. }\end{array}$ & $\begin{array}{l}\text { Diz a tradicção que Ceará significa na.língua indígena - canto de jandaia. } \\
\text { Ayres do Casal, Congraphia Brasilica, refere essa tradicção. O senador } \\
\text { Pompêo em seu excellente diccionario topographico menciona uma } \\
\text { opinião, nova para mim, que pretende vir Siará da palavra suia-caça, em } \\
\text { virtude da abundância de caça que se encontrava nas margens do rio. Essa } \\
\text { ethmologia é forçada. Para designar quantidade, usava a língua tupy da } \\
\text { desinencia iba; a desinencia ára junta, ãos verbos designa o sujeito que } \\
\text { exercita a acção actual; junta aos nomes o que tem actualmente o objecto } \\
\text { - exp. Coatyara - o que pinta - Jussara - o que tem espinho.Ceará } \\
\text { é nome composto de cemo - cantar forte, clamar, e ara, pequena arara } \\
\text { ou periquito. Essa é a ethmologia verdadeira, e não só conforme com a } \\
\text { tradicção, mas com as regras da língua. }\end{array}$ \\
\hline Giraó & $\begin{array}{l}\text { Na jangada é uma espécie de estrado onde acommodão os passageiros: e } \\
\text { as vezes o cobrem de palha. Em geral é qualquer estiva elevada do solo e } \\
\text { zuspensa em forquilhas. }\end{array}$ \\
\hline Rugitar & $\begin{array}{l}\text { é um verbo de minha composição para o qual peço venia. Felinto Elisio } \\
\text { creou ruidar de ruido. }\end{array}$ \\
\hline Iracema & $\begin{array}{l}\text { Em guarany significa lábios de mel—de ira —mel e tembe labios. Tembe } \\
\text { na composição altera-se em ceme, como na palavra ceme-yba. }\end{array}$ \\
\hline Grauna & $\begin{array}{l}\text { é o pássaro conhecido de côr negra luzidia.-Seu nome vem por corrupção } \\
\text { de guira pássaro e una; abreviação de pixuna, preto. }\end{array}$ \\
\hline Jaty & Pequena abelha que fabrica delicioso mel. \\
\hline Ipú & $\begin{array}{l}\text { Chamão ainda hoje no Ceará certa qualidade de terra muito fertil, que } \\
\text { fórma grandes corôas ou ilhas no meio dos taboleiros e sertões, e é de } \\
\text { preferencia procurada para a cultura. Dahi se deriva o nome dessa comarca } \\
\text { da provincia. }\end{array}$ \\
\hline Tabajaras & $\begin{array}{l}\text { Senhores das aldeias — de taba-aldeia-e - jara senhor. Essa nação } \\
\text { dominava o interior da provincia, especialmente a Serra da Ibyapaba. }\end{array}$ \\
\hline Oitycica & $\begin{array}{l}\text { Arvore frondosa, apreciada pela deliciosa frescura que derrama sua } \\
\text { sombra. }\end{array}$ \\
\hline
\end{tabular}

continua

11 Edição disponível na Biblioteca Brasiliana: https://igital.bbm.usp.br/handle/ bbm/4660?locale $=$ en

Confluência. Rio de Janeiro: Liceu Literário Português, n. 61, p. 66-98, jul.-dez. 2021 


\begin{tabular}{|c|c|}
\hline Gará & $\begin{array}{l}\text { Ave palludal, muito conhecida pelo nome de guará. Penso eu que esse nome } \\
\text { anda corrompido de sua verdadeira origem que é-ig, água e ará, arara; } \\
\text { arara d'agua, pela bella côr vermelha. }\end{array}$ \\
\hline Ará & $\begin{array}{l}\text { periquito. Os indígenas como augmentativo usavão repetira ultima sillaba da } \\
\text { palavra e as vezes toda a palavra - como murémuré. Muré - frauta - } \\
\text { muremuré grande frauta. Arára vinha a ser pois o augmentativo de ará, e } \\
\text { significaria a espécie maior do gênero. }\end{array}$ \\
\hline Urú & $\begin{array}{l}\text { Cestinho que servia de cofre ás selvagens para guardar seus objectos de mais } \\
\text { preço e estimação. }\end{array}$ \\
\hline Crautá & Bromelia vulgar, de que se tirao fibras tão ou mais finas que as do linho. \\
\hline Jussara & $\begin{array}{l}\text { Palmeira de grandes espinhos, das quaes servem-se ainda hoje para dividir os } \\
\text { fios da renda. }\end{array}$ \\
\hline Uiraçaba & aljava-de uira seta e á desinencia-caba-cousa própria. \\
\hline $\begin{array}{l}\text { Quebrar a } \\
\text { frecha }\end{array}$ & $\begin{array}{l}\text { Era entre os indigenas a maneira symbolica de estabelecerem a paz entre } \\
\text { as diversas tribus, ou mesmo entre dois guerreiros ennemigos. Desde já } \\
\text { advertimos que não se extranhe a maneira porque o estrangeiro se esprime } \\
\text { fallando com os selvagens: ao seu perfeito conhecimento dos usos e lingua } \\
\text { dos indigenas, e sobretudo á ter-se conformado com elles aponto de deixar } \\
\text { os trajos europeos e pintar-se, deveu Martim Soares Moreno a influencia } \\
\text { que adquirio entre os índios do Ceará. }\end{array}$ \\
\hline Ibyapaba & $\begin{array}{l}\text { Grande serra que se prolonga ao norte da província e a extrema com } \\
\text { Piauhy. Significa terra aparada. O Dr. Martius em seu glossario lhe } \\
\text { attribue outra athmologia. Iby -terra - e pabe - tudo. A primeira porém } \\
\text { tem a authoridade de Vieira. }\end{array}$ \\
\hline Igaçaba & de ig-aguá e a desinencia çaba — cousa própria. \\
\hline Vieste & $\begin{array}{l}\text { A saudaçãousualdahospitalidade eraesta._Ereioubê-tuvieste?Pa-aiotu, } \\
\text { vim, sim. Auge-be, bem dito. Veja-se Lery, pag. } 286 \text {. }\end{array}$ \\
\hline Jaguaribe & $\begin{array}{l}\text { maior rio da província; tirou o nome da quantidade de onças que povoavão } \\
\text { suas margens. Jaguar - onça }-i b a-\text { desinencia para exprimir copia, } \\
\text { abundancia. }\end{array}$ \\
\hline Martim & $\begin{array}{l}\text { Da origem latina de seu nome, procedente de Marte, deduz o estrangeiro á } \\
\text { significação que lhe dá. }\end{array}$ \\
\hline
\end{tabular}




\begin{tabular}{|c|c|}
\hline Pytiguaras & $\begin{array}{l}\text { Grandenaçãodeindiosquehabitavaolittoraldaprovinciaeestendia-sedesdeo } \\
\text { ParnaybaatéoRioGrandedoNorie. Aorthographiadonomeandamuiviciada } \\
\text { nas differentes versões pelo que se tornou difficil conhecer a ethmologia. } \\
\text { Iby significava terra; iby-tira veio a significar serra, ou terra alta. Aos } \\
\text { valles chamavão os indígenas iby-tira-cua-cintura das montanhas. A } \\
\text { desinencia jara senhor, acrescentada formou a palavra Ibyticuara-que } \\
\text { por corrucção* deu Pytiguara - senhores dos valles. }\end{array}$ \\
\hline $\begin{array}{l}\text { Mão espirito } \\
\text { da floresta }\end{array}$ & $\begin{array}{l}\text { Os indígenas chamavão á esses espíritos caà-pora habitantes da mata, donde } \\
\text { por corrupção veio a palavra eâipora iútròduzida na língua portugneza em } \\
\text { sentido figurado. }\end{array}$ \\
\hline $\begin{array}{l}\text { As mais bellas } \\
\text { mulheres }\end{array}$ & $\begin{array}{l}\text { Este costume da hospitalidade americana é attestado pelos chronistas. A } \\
\text { elle se attribue o bello rasgo de virtude de Anchieta, que para fortalecer } \\
\text { a sua castidade, compunha nas praias de Iperoig o poema da Virgindade } \\
\text { de Maria, cujos versos escrevia nas areias humidas, para melhor os polir. }\end{array}$ \\
\hline Jurema & $\begin{array}{l}\text { Arvore mean, de folhagem espessa; dá um fructo excessivamente amargo, } \\
\text { de cheiro acre, do qual juntamente com as folhas e outros ingredientes } \\
\text { preparavão os selvagens uma bebida, que tinha o effeito do hatchis, de } \\
\text { produzir sonhos tão vivos e intensos, que a pessoa fruia nelles melhor do } \\
\text { que na realidade. A fabricação desse licor era um segredo, explorado pelos } \\
\text { Pagés, em proveito de sua influencia. Jurema é composto de ju-espinho e } \\
\text { rema cheiro desagradável. }\end{array}$ \\
\hline Irapuam & $\begin{array}{l}\text { de ira-mel e apuam redondo: é o nome dado á uma abelha virulenta e brava, } \\
\text { por causa da forma redonda de sua calmea. Por corrupção reduzio-se esse } \\
\text { nome actualmente á arapuá. O guerreiro de que se trata aqui é o celebre } \\
\text { Mel-redondo, assim chamado pelos chronistas do tempo que traduzião seu } \\
\text { nome ao pé da lettra. Mel-redondo chefe dos Tabajaras da serra Ibyapaba } \\
\text { foi encarniçado inemigo dos Portuguezes, e amigo dos Francezes. }\end{array}$ \\
\hline Acaraú & $\begin{array}{l}\text { O nome do rio é Acaracú - de acará garça - co-buraco, toca, ninho, e y- } \\
\text { som dúbio entre i e u, que os portuguezes, ora exprimião de um, ora de outro } \\
\text { modo, significando agua. Rio do ninho das garças é pois a traducçâo de } \\
\text { Acaracú; e rio das garças a de Acaraú. Usou-se aqui da liberdade horaciana } \\
\text { para evitar em uma obra litteraria, obra de gosto e artistica, um som áspero } \\
\text { e ingrato. De resto quem sabe si o nome primitivo não foi realmente Acaraú, } \\
\text { que se alterou como tantos outros, pela introducção da consoante? }\end{array}$ \\
\hline Estrella morta & $\begin{array}{l}\text { A estrella polar por causa de sua mimobilidade; orientavão-se por ella os } \\
\text { selvagens durante a noite. }\end{array}$ \\
\hline
\end{tabular}




\begin{tabular}{|c|c|}
\hline Boiciminga & a cobra cascavel-de boia, cobra e cininga chocalho. \\
\hline $\begin{array}{l}\text { Espiritos da } \\
\text { treva }\end{array}$ & $\begin{array}{l}\text { esses espiritos chamavão os selvagens curupira, meninos máos-de } \\
\text { curumim, menino, e pira máo. }\end{array}$ \\
\hline Boré & frauta de bambu, - o mesmo que muré. \\
\hline Ocara & $\begin{array}{l}\text { praça circular que ficava no centro da taba, cercada pela estacada, e para a } \\
\text { qual abrião todas as casas. Composto de } o c a \text {, casa e a desinencia ara, que } \\
\text { tem; aquillo que tem a casa, ou onde a casa está. }\end{array}$ \\
\hline Potyuara & $\begin{array}{l}\text { comedor de camarão ; de poty - e uara. Nome que por despreso davão } \\
\text { os ennemigos aos Pytiguaras, que habitavão as praias e vivião em grande } \\
\text { parte de pesca. Este nome dão alguns escriptores aos Pytiguaras, porque os } \\
\text { receberão de seus ennemigos. }\end{array}$ \\
\hline Pocema & $\begin{array}{l}\text { grande alarido que faziao os selvagens nas occasiões solemnes como em } \\
\text { começo de batalha, ou nas expansões da alegria; é palavra adoptada ja na } \\
\text { língua portugueza e inserida no diccionario de Moraes. Vem de pomão } \\
\text { e cemo clamar; clamor das mãos, porque os selvagens acompanhavão o } \\
\text { vozear com o bater das palmas e das armas. }\end{array}$ \\
\hline Andira & $\begin{array}{l}\text { morcego: é em allusão á seu nome que Irapuam dirige logo palavras de } \\
\text { despreso ao velho guerreiro. }\end{array}$ \\
\hline Acacaty & $\begin{array}{l}\text { Significava este nome bom tempo de ara e cátú. Os selvagens } \\
\text { do sertão assim chamavão as brisas do mar que sopprão } \\
\text { regularmente ao cahir da tarde, e correndo pelo valle do Jaguaribe } \\
\text { se derramão pelo interior e refrigerão da calma abrasadora } \\
\text { do verão. Dahi resultou chamar-se Aracaty o lugar de onde vinha a monção. } \\
\text { Ainda hoje no Icó o nome é conservado a brisa da tarde, que sopra do mar. }\end{array}$ \\
\hline Afflar & $\begin{array}{l}\text { Sobre este verbo que introduzi na linua portugueza do latim afflo, já escrevi } \\
\text { o que entendi em nota de uma segunda edicção da Diva que brevemente } \\
\text { ha de vir a luz. }\end{array}$ \\
\hline Anhanga & $\begin{array}{l}\text { Davão os indígenas este nome ao espirito do mal; compõe-se de anho só e } \\
\text { anga alma. Espirito só, privado de corpo, fantasma. }\end{array}$ \\
\hline Camocim & $\begin{array}{l}\text { vaso onde encerravão os indigenas os corpos dos mortos e lhes servia } \\
\text { de túmulo; outros , dizem camotim, e talvez com melhor orthographia, } \\
\text { porque se não me engano o nome é corrupção da frase com buraco ambyra } \\
\text { defuncto anhotim enterrar - buraco para entrar ô defuncto- }-c^{\prime} \text { am' otim. } \\
\text { O some dava-se também á qualquer pote. }\end{array}$ \\
\hline
\end{tabular}




\begin{tabular}{|c|c|}
\hline Guabiroba & Deve ler-se Andiroba. Arvore que dá um azeite amargo. \\
\hline Cabellos do sol & $\begin{array}{l}\text { em tupy guaraciaba. Assim chamavão os europeos que tinhao os cabellos } \\
\text { louros }\end{array}$ \\
\hline Moquem & $\begin{array}{l}\text { Do verbo mocaém assar na labareda. Era a maneira porque os indigenas } \\
\text { conservavão a caça para não apodrecer, quando a levavão em viagem. Nas } \\
\text { cabanas a tinhão no fumeiro. }\end{array}$ \\
\hline $\begin{array}{l}\text { Senhor do } \\
\text { caminho }\end{array}$ & assim chamavão os indígenas ao guia — de py-caminho e guara, senhor. \\
\hline $\begin{array}{l}\text { O dia vae ficar } \\
\text { triste }\end{array}$ & $\begin{array}{l}\text { Os tupys chamavão a tarde carúca, segundo o diccionario: segundo } \\
\text { Lery, che caruc acy, significa-« estou triste.» Qual destes era o sentido } \\
\text { figurado da palavra? Tirarão a imagem da tristesa, da sombra da tarde, ou } \\
\text { a imagem do crepúsculo do torvamento do espirito? }\end{array}$ \\
\hline Jurupary & demonio; de juruboca e apara, torto, alejado. O boca torta. \\
\hline Ubaia & $\begin{array}{l}\text { fructa conhecida da espécie engema. Significa fructa saudável de } u b a \text {-fmctae } \\
\text { aia saudavel. }\end{array}$ \\
\hline Jandaia & $\begin{array}{l}\text { Este nome que anda escripto por diversas maneiras nhendaia, } \\
\text { nhandaia e em todas alterado é apenas um adjectivo qualificativo } \\
\text { do substantivo ará. Deriva-se elle das palavras nheng-fallar - } \\
\text { antan, duro, forte, áspero, e ara desinencia verbal que exprime o } \\
\text { agente - } n h^{\prime} a n t^{\prime} \text { ara; substituído o } t \text { por } d-\text { e o } r \text { por } i \text {, tornou-se } \\
\text { nhandaia, donde jandaia, que se traduzirá por periquito grasnador. } \\
\text { Do canto desta ave, como se vio, é que vem o nome de Ceará, segundo a } \\
\text { ethmologia que lhe dá a tradicção. }\end{array}$ \\
\hline Inhuma & $\begin{array}{l}\text { Ave nocturna palamedea. A especie de que se falla aqui é a palamedea } \\
\text { chavaria, que canta regularmente a meia-noite. A orthografia melhor } \\
\text { creio ser anhuma, talvez do anho, só, e anum, ave agoureira condecida. } \\
\text { Significaria então anum solitario, assim chamado pela tal ou qual } \\
\text { semelhança do grito desagradável. }\end{array}$ \\
\hline Inubia & $\begin{array}{l}\text { Trombeta de guerra. Os indigenas, segundo Lery, as tinhao tão grandes } \\
\text { que medião um deametro na abertura. }\end{array}$ \\
\hline Guará & $\begin{array}{l}\text { Cão selvagem, lobo brasileiro. Provem esta palavra do verbo } u \text { comer, } \\
\text { do qual se forma com o relativo } \mathrm{G} \text { e a desinencia ara o verbal } g \text { - } u \text {-ára } \\
\text { comedor. A sillaba final longa é a partícula propositiva ã que serve para dar } \\
\text { forca a palavra. } G \text { - } u \text {-ára-ã realmente comedor, voraz. }\end{array}$ \\
\hline
\end{tabular}




\begin{tabular}{|c|c|}
\hline Giboa & $\begin{array}{l}\text { Cobra conhecida: de gi machado e boia cobra. O nome foi tirado da } \\
\text { maneira porque a serpente lança o bote, semelhante ao golpe do machado; } \\
\text { pode traduzir-se bem, cobra de arremesso. }\end{array}$ \\
\hline Sucury & $\begin{array}{l}\text { A serpente gigante que habita nos grandes rios e engole um boi. De Suu, } \\
\text { animal e cury ou curu roncador. Animal roncador, porque de feito o ronco } \\
\text { da sucury é medonho. }\end{array}$ \\
\hline $\begin{array}{l}\text { Si é que tens } \\
\text { sangue e não } \\
\text { mel }\end{array}$ & $\begin{array}{l}\text { Allusão que faz o velho Andira ao nome de Irapuam, e qual como se disse } \\
\text { significa mel redondo. }\end{array}$ \\
\hline $\begin{array}{l}\text { Ouve seu } \\
\text { trovão }\end{array}$ & $\begin{array}{l}\text { Todo esse episódio do rugido da terra é uma astucia, como usavão os pajés } \\
\text { e os sacerdotes de toda a nação selvagem para imporem á imaginação } \\
\text { do povo. A cabana estava assentada sobre um rochedo, onde havia uma } \\
\text { galeria subterrânea que communicava com a varsea por estreita abertura; } \\
\text { Araken tivera o cuidado de tapar com grandes pedras as duas aberturas, } \\
\text { para occultar a gruta dos guerreiros. Nessa occasião a fenda inferior estava } \\
\text { aberta e o Pagé o sabia ; abrindo a fenda superior, o ar encanou-se pelo } \\
\text { antro espiral com estrielor medonho, e de que pode dar uma idéa o sussurro } \\
\text { dos caramujos.-O facto é pois natural; a apparencia sim é maravilhosa. }\end{array}$ \\
\hline Abaty n'agua & $\begin{array}{l}\text { Abaty — arroz; Iracema serve-se da imagem do arroz que só viça no } \\
\text { alagado, para exprimir sua alegria }\end{array}$ \\
\hline Ubiratan & Páo ferro de ubira; - páo e antan duro. \\
\hline Maracajá & Gato selvagem. \\
\hline Caetetus & $\begin{array}{l}\text { Porco do mato, espécie de javalí brasileiro. De caeté-mato grande e } \\
\text { virgem-》 e suu caça, mudado o } s \text { em } t \text { na composição pela euphoniada } \\
\text { língua. Caça do mato virgem. }\end{array}$ \\
\hline Jaguar & $\begin{array}{l}\text { Vimos que guará significa voraz. Jaguar tem inquestionavelmente a mesma } \\
\text { ethmologia; é o verbal guara e o pronome ja nós. Jaguar era pois para os } \\
\text { indígenas todos os animaes que os devoravão. Jaquareté o grande devorador. }\end{array}$ \\
\hline Anagê & Gavião. \\
\hline Acauan & $\begin{array}{l}\text { Acauan, ave ennemiga das cobras - de caa páu e uan — do verbo } u \text {, que } \\
\text { come páo. }\end{array}$ \\
\hline Sahy & Lindo passaro azul. \\
\hline
\end{tabular}




\begin{tabular}{|c|c|}
\hline Carioba & $\begin{array}{l}\text { Camisa de algodão, de cary branco e oba roupa. Tinhao também a arassoia } \\
\text { de arára e } o b a \text {, vestido de pennas de arara. }\end{array}$ \\
\hline $\begin{array}{l}\text { A' cintura da } \\
\text { virgem }\end{array}$ & $\begin{array}{l}\text { Os indígenas chamavão a amante possuída aguaçaba, de } a b a \text {, homem, } \\
c u a \text {, cintura, caba, cousa própria; a mulher que o homem cinge, ou traz á } \\
\text { cintura. Fica pois claro o pensamento de Iracema. }\end{array}$ \\
\hline Jacy & $\begin{array}{l}\text { Alua. De } j a ́ \text {-pronome, nós, } c y \text { - mãe. - A lua exprimia o mez para os } \\
\text { selvagens; e seu nascimento era sempre por elles festejado. }\end{array}$ \\
\hline $\begin{array}{l}\text { Fogos da } \\
\text { alegria }\end{array}$ & $\begin{array}{l}\text { Chamavão os selvagens tory, os faxos ou fogos; e toryba, a alegria, a festa, } \\
\text { a grande copia de faxos. }\end{array}$ \\
\hline Bucan & $\begin{array}{l}\text { Significa uma espécie de grelha que os selvagens fazião para assar a caça; } \\
\text { dahi vem o verbo francez boucaner. A palavra e da lingua tupy. }\end{array}$ \\
\hline Acoty & cotia \\
\hline Abactè & varão abalisado; de $a b a$ - homem e etè-forte, egrégio. \\
\hline Jacaúna & $\begin{array}{l}\text { jacarandá preto-de jaca, abreviação de jacarandá, e una, preto. Este } \\
\text { Jacaúna é o celebre chefe, amigo de Martim Soares Moreno. }\end{array}$ \\
\hline Coandù & porco espinho \\
\hline $\begin{array}{l}\text { Seu collar de } \\
\text { guerra }\end{array}$ & $\begin{array}{l}\text { O collar que os selvagens fazião dos dentes dos ennemigos vencidos era } \\
\text { um brasão e tropheo de valentia. }\end{array}$ \\
\hline Japy & significa, nosso pé, de já - pronome, nós e py pé. \\
\hline Ibyapina & De Iby-terra e apino, tosquiar. \\
\hline Jatobá & $\begin{array}{l}\text { grande arvore real. O lugar da scena é o sitio da hoje Villa Viçosa, onde diz a } \\
\text { tradicção ter nascido Camarão. }\end{array}$ \\
\hline Meruoca & De meru, mosca, e oca, casa. Serra junto de Sobral fértil em mantimentos. \\
\hline Uruburetama & pátria ou ninho de urubus : serra bastante alta. \\
\hline Mundahu & $\begin{array}{l}\text { rio muito tortuoso que nasce na serra de Uruburetama. Mundé, cilada, e } \\
h u \text { rio. }\end{array}$ \\
\hline Polengi & rio que rega a cielade do Natal, donde era filho Soares Moreno \\
\hline $\begin{array}{l}\text { As saborosas } \\
\text { trahiras }\end{array}$ & $\begin{array}{l}\text { E'o rio Trahiry trinta leguas ao norte da capital. De trahira, peixe e } y \text {, rio. } \\
\text { Hoje é povoaçao e destricto de paz. }\end{array}$ \\
\hline
\end{tabular}




\begin{tabular}{|c|c|}
\hline Soipé & $\begin{array}{l}\text { paiz da caça. De Sôo caça, e ipè, lugar onde. Diz-se hoje Siupé, rio e } \\
\text { povoaçao pertencente á freguezia e termo da Fortaleza, situada á margem } \\
\text { dos alagados chamados Jaguarussú na embocadura do rio. }\end{array}$ \\
\hline Pacoty & $\begin{array}{l}\text { rio das pacohas. Nasce na serra de Baturité e lança-se no oceano duas } \\
\text { legoas ao norte de Aquirás. }\end{array}$ \\
\hline Iguape & $\begin{array}{l}\text { enseada distante duas legoas de Aquirás. De } I g \text {, água, cua, centura e ipé, } \\
\text { onde. }\end{array}$ \\
\hline Moco & $\begin{array}{l}\text { morro de areia na enseada do mesmo nome á uma legua da Fortaleza; diz- } \\
\text { se hoje Mucuripe. Vem de Corib alegrar e mo, particula ou abreviatura do } \\
\text { verbo monhang fazer, que se junta aos verbos neutros e mesmo activos para } \\
\text { dar-lhes significação passiva - exp. caneon, affligir-se, mocaneon fazer } \\
\text { alguem afflicto. }\end{array}$ \\
\hline $\begin{array}{l}\text { Rio que forma } \\
\text { um braço de } \\
\text { mar }\end{array}$ & $\begin{array}{l}\text { E' o Parnahyba, rio de Piauhy. Vem de Pará, mar, nhanhe, correr e hyba, } \\
\text { braço; braço corrente do mar. Geralmente se diz que Pará significa rio e } \\
\text { Paraná mar; é inteiramente o contrario. }\end{array}$ \\
\hline Mayry & $\begin{array}{l}\text { cidade. Talvez provenha o nome de mayr estrangeiro, e fosse applicado } \\
\text { aos povoados dos brancos em opposição ás tabas dos indios. }\end{array}$ \\
\hline $\begin{array}{l}\text { Brancos } \\
\text { tapuios }\end{array}$ & $\begin{array}{l}\text { em tupy, tapuitinga. Nome que os Pytiguaras davão aos francezes para } \\
\text { differença-los dos Tupinambás. Tapuia, significa bárbaro, ennemigo. De } \\
\text { taba, aldeia e puyr fugir —os fugidos da aldeia. }\end{array}$ \\
\hline Balu & $\begin{array}{l}\text { narseja illustre, de batuira e etê. Appellido que tomára o chefe pytiguara, e } \\
\text { que na linguagem figurada valia tanto como valente nadador. E' o nome de } \\
\text { uma serra fertilissima e da comarca que ella occupa. }\end{array}$ \\
\hline $\begin{array}{l}\text { Suas estrellas } \\
\text { erão muitas }\end{array}$ & $\begin{array}{l}\text { Conta vão os indígenas os annos pelo nascimento das pleiades no oriente ; } \\
\text { e também costumavão guardar uma castanha de cada estação de caju, para } \\
\text { marcar a idade. }\end{array}$ \\
\hline Jatobá & $\begin{array}{l}\text { arvore frondoza, talvez de jetahi, oba, folha e } a \text {, augmentativo; jetahy de } \\
\text { grande copa. E' nome de um rio e de uma serra em S. Quiteria. }\end{array}$ \\
\hline Quixeramobim & $\begin{array}{l}\text { segundo e Dr. Martius traduz-se por essa exclamação do saudade. Compõe- } \\
\text { se de Qui, ah!, xere, meus, amôbinhê, outros tempos. }\end{array}$ \\
\hline $\begin{array}{l}\text { Caminho das } \\
\text { garças }\end{array}$ & $\begin{array}{l}\text { Em tupy Acarape, povoaçao na freguezia de Baturite á nove leguas da } \\
\text { capital. }\end{array}$ \\
\hline
\end{tabular}




\begin{tabular}{|c|c|}
\hline Maranguab & $\begin{array}{l}\text { A serra da Maranguape distante cinco léguas da capital, e notável pela sua } \\
\text { fertilidade e formosura, O nome indígena compõe-se de maran guerrear } \\
\text { e coaub sabedor; maran, talvez seja abreviação de maramonhang, fazer } \\
\text { guerra, se não é, como eu penso, o substantivo simples guerrear, de que } \\
\text { se fez o verbo composto. O Dr. Martius traz ethmologia diversa. Mara, } \\
\text { arvore, angai, de nenhuma maneira, guabe, comer. Esta ethmologia nem } \\
\text { me parece própria ao objecto que e uma serra, nem conforme com os } \\
\text { preceitos da lingua. }\end{array}$ \\
\hline Pirapora & $\begin{array}{l}\text { Rio de Maranguape, notável pela frescura de suas águas e excellencia dos } \\
\text { banhos chamados da Pirapora, no lugar das cachoeiras. Provem o nome de } \\
\text { Pira, peixe, pore, salto : salto do peixe. }\end{array}$ \\
\hline $\begin{array}{l}\text { O gavião } \\
\text { branco }\end{array}$ & $\begin{array}{l}\text { Batuireté chama assim o guerreiro branco-, ao passo que trata o neto por } \\
\text { narseja : elle prophetisa nesse parallello a destruição de sua raça pela raça } \\
\text { branca. }\end{array}$ \\
\hline Porangaba & $\begin{array}{l}\text { Significa bellesa. E uma lagoa distante da cidade ume légua em sitio } \\
\text { aprasivel. Hoje a chamão Arronches: e as suas margens está a decadente } \\
\text { povoaçao do mesmo nome. }\end{array}$ \\
\hline Jererahu & $\begin{array}{l}\text { rio das marrecas; de jerere -ou irerê, marreca, e } h u \text {, água. Este lugar } \\
\text { ainda hoje é notável pela excellencia da fructa, com especialidade as bellas } \\
\text { laranjas conhecidas por laranjas de Jererahu. }\end{array}$ \\
\hline Sapiranga & $\begin{array}{l}\text { lagoa no sitio Alagadiço Novo, a cerca de } 2 \text { léguas da capital. O nome } \\
\text { indígena significa olhos vermelhos, de ceça, olhos e piranga, vermelhos. } \\
\text { Esse mesmo nome dão usualmente no norte a certe ophtalmia. }\end{array}$ \\
\hline Murityapuá & $\begin{array}{l}\text { De murity - nome da palmeira mais vulgarmente conhecida por burity, e } \\
\text { apuam, ilha. Lugarejo no mesmo sitio referido. }\end{array}$ \\
\hline Aratanha & $\begin{array}{l}\text { de } \text { arara, ave e tanha, dente. Serra mui fértil e cultivada em continuação } \\
\text { da de Maranguape. }\end{array}$ \\
\hline Pacatuba & $\begin{array}{l}\text { De paca e tuba, leito ou couto das pacas. Recente, mas importante } \\
\text { povoaçao, em um bello valle da serra da Aratanha. }\end{array}$ \\
\hline Guayúba & $\begin{array}{l}\text { De goaia, valle, } y \text {, água, jur, vir, be, por onde; por onde vem as águas do } \\
\text { valle. Rio que nasce na serra da Aratanha e corta a povoaçao do mesmo } \\
\text { nome á seis léguas da capital. }\end{array}$ \\
\hline Ambar & $\begin{array}{l}\text { As praias do Ceará erão nesse tempo muito abundantes de âmbar que o mar } \\
\text { arrojava. Chamavão-lhe os indígenas, Pira repoti, estéreo de peixe. }\end{array}$ \\
\hline
\end{tabular}

continua

Confluência. Rio de Janeiro: Liceu Literário Português, n. 61, p. 66-98, jul.-dez. 2021 


\begin{tabular}{|c|c|}
\hline Coatyá & $\begin{array}{l}\text { pintar. A historia, menciona esse facto de Martim Soares Moreno se ter } \\
\text { coatyado quando vivia entre os selvagens do Ceará. }\end{array}$ \\
\hline Coat & $\begin{array}{l}\text { A desinencia } a b o \text { significar o objecto que soffreu a acção do verbo, e talvez } \\
\text { provenha de } a b a \text {, gente, creatura. }\end{array}$ \\
\hline Colibri & Desse lethargo do colibri no inverno falia Simão de Vasconcellos. \\
\hline Mocejana & $\begin{array}{l}\text { Lagoa e povoaçao a } 2 \text { léguas da capital. O verbo cejar significa- } \\
\text { abandonar; a desinencia ana indica a pessoa que exercita a acção do } \\
\text { verbo. Cejana-significa o que abandona. Junta a particula mo do verbo } \\
\text { monhang, fazer, vem a palavra a significar o que fez abandonar ou que foi } \\
\text { lugar e occasião de abandonar. }\end{array}$ \\
\hline Carbeto & $\begin{array}{l}\text { Espécie de serão que faziâo os indios á noite em uma caoana maior, onde } \\
\text { todos se reunião para conversar. Leia-se Ives D'Evreux: Viagem ao norte } \\
\text { do Brasil. }\end{array}$ \\
\hline Monguba & $\begin{array}{l}\text { Arvore que dá um fructo cheio de cotâo. semelhante ao da sumauma, } \\
\text { com a differença de ser negro. Dahi veio o nome a uma parte da serra } \\
\text { de Maranguape onde tem estabelecimento rural o tenente coronel João } \\
\text { Franklin de Alencar. }\end{array}$ \\
\hline Imbú & $\begin{array}{l}\text { Fructa da serrado Araripe que não vem no littoral. E' saborosa e semelhante } \\
\text { ao cajá. }\end{array}$ \\
\hline Jacarecanga & $\begin{array}{l}\text { Morro de areia na praia do Ceará, afamado pela fonte de água fresca } \\
\text { puríssima. Vem o nome de Jacaré, crocodilho e acanga cabeça. }\end{array}$ \\
\hline Japim & $\begin{array}{l}\text { Pássaro côr de ouro com encontros pretos e conhecido vulgarmente pelo } \\
\text { nome de soffrer. }\end{array}$ \\
\hline Folha escura & $\begin{array}{l}\text { Folha escura, a muita, que os indígenas chamava capixuna - de caa- } \\
\text { rama, folhagem, e pixuna escuro. Dahi vem a figura de que usa Iracema } \\
\text { para exprimir a tristesa que ella produz no esposo. }\end{array}$ \\
\hline Tupinambás & $\begin{array}{l}\text { Nação formidável, ramo primitivo da grande raça tupy. Depois de uma } \\
\text { resistência heróica, não podendo expulsar os portuguezes da Bahia } \\
\text { emigrarão até o Maranhão onde fizerão allianca com os francezes que já } \\
\text { então infestavão aquellas paragens. O nome que elles se davão significa- } \\
\text { gente parente dos Tupvs - de Tupy — anama-aba. }\end{array}$ \\
\hline Maracatim & $\begin{array}{l}\text { Grande barco que levava na proa-tim-um maracá. Aos barcos menores } \\
\text { ou canoas chamavão igara—de ig-água—ejara, senhor; senhora d'agua. }\end{array}$ \\
\hline
\end{tabular}




\begin{tabular}{|l|l|}
\hline Caiçara & $\begin{array}{l}\text { Caiçara, de cai, pau queimado e a desinencia cara, cousa que tem, ou se } \\
\text { faz. O que se faz de pau queimado. Era uma forte estacada de pau a pique. }\end{array}$ \\
\hline $\begin{array}{l}\text { Bahia dos } \\
\text { papagaios }\end{array}$ & $\begin{array}{l}\text { E a bahia da Jericoacoara, de jeru, papagaio, cua, várzea, coara, buraco } \\
\text { ou seio; enseada da várzea dos papagaios. E' um dos bons portos do Ceará. }\end{array}$ \\
\hline Moacyr & $\begin{array}{l}\text { Filho do sofrrimento-de moacy, dôr e ira desinencia, que significa } \\
\text { sahido de }\end{array}$ \\
\hline Faxa & $\begin{array}{l}\text { E' o que chamão vulgarmente typoia; rejeitou-se o termo próprio, do testo } \\
\text { por andar degradado no estylo chulo. }\end{array}$ \\
\hline $\begin{array}{l}\text { Chupou tua } \\
\text { alma }\end{array}$ & $\begin{array}{l}\text { Creança em tupy é pitanga, de piter chupar e anga alma; chupa alma. } \\
\text { Seria porque as crenças attrahem e deleitão aos que as vêem; ou porque } \\
\text { absorvem uma porção dalma dos pães? Cauby falia nesse ultimo sentido. }\end{array}$ \\
\hline Cariman & $\begin{array}{l}\text { Uma conhecida preparação de mandioca. Caric, correr, mani, mandioca. } \\
\text { Mandioca escorrida. }\end{array}$ \\
\hline Tauape & $\begin{array}{l}\text { Tauape, lugar de barro amarello, de tauá e ipê. Fica no caminho de } \\
\text { Maranguape, }\end{array}$ \\
\hline Piau & $\begin{array}{l}\text { Piau, peixe que deu o nome ao rio Piauhy, } \\
\text { diccionario. }\end{array}$ \\
\hline Velha-taba & $\begin{array}{l}\text { traducção de tapui-tapera. Assim chamava-se um dos estabelecimentos dos } \\
\text { Tupinambás no Maranhão. }\end{array}$ \\
\hline casa de pedra, fortaleza.
\end{tabular}

\title{
Referências bibliográficas
}

\author{
ABREU, Mirhiane Mendes de. Ao pé da página: a dupla narrativa de José \\ de Alencar. Campinas, SP: Mercado das Letras, 2011. \\ AGUIAR, Maycon Silva; MOURA, Jonathan Ribeiro Farias de. Entrevista \\ com José Horta Nunes. Policromias - Revista de Estudo do Discurso, \\ Imagem e Som, [S.1.], v. 2, n. 2, p. 155-162, dez. 2017. ISSN 2448-2935.
}

Confluência. Rio de Janeiro: Liceu Literário Português, n. 61, p. 66-98, jul.-dez. 2021 
ALENCAR, José de. O Guarani. Rio de Janeiro: Empreza Nacional do Diario, 1857.

. Iracema. Rio de Janeiro: Typ. de Viana \& Filhos, 1865.

AUROUX, Sylvain. A revolução tecnológica da gramatização. Campinas, São Paulo: Unicamp, 1992.

ESTEVES, Phellipe Marcel da Silva. Discurso sobre alimentação nas enciclopédias do Brasil: Império e Primeira República. Niterói: Eduff, 2017.

GUILHAUMOU, Jacques; MALDIDIER, Denise. Efeitos do arquivo: a análise do discurso no lado da História. In: ORLANDI, E. P. (Org.). Gestos de Leitura: da História no Discurso. Campinas: Ed. da UNICAMP, p.163183, 1994.

GUIMARÃES, Eduardo. Sinopse dos estudos do português no Brasil: a gramatização brasileira. Língua e Cidadania. O Português no Brasil. Campinas, Pontes, 1996. p. 127-138.

MEDEIROS, Vanise. Cartografias das línguas: Glossários para livros de literatura. Revista Alfa, São Paulo, v.60, n.1, p.79-93, 2016.

. Na urdidura das notas de rodapé, arquivos da língua. In: Venturini, Mara Cleci. (Org.). Museus, arquivos e produção do conhecimento em (dis) curso. 1ed. Campinas: Pontes, 2017. p. 89-108.

- Memória e singularidade no gesto do escritor-lexicógrafo. Confluência, [S.1.], p. 143-156, jan. 2014.

Les glossaires brésiliens dans la littérature : les savoirs sur la langue. Publicado: Dossiers d'HEL, SHESL, Analyse et exploitation des données de corpus linguistiques, Vol 10, Num 11, pp.67-79, 2017.

. A retórica da mediação: dois momentos. Linguagem em (dis)curso, [S.1.], v. 19, n. 2, p. 355-371, jul. 2019. 
. Projeto Arquivos da Língua: Taunay, CNPq (PIBIC), 2015.

NUNES, José Horta. O discurso documental na História das Idéias Lingüísticas e o caso dos dicionários. Alfa: Revista de Linguística (UNESP. Impresso) , v. 52, p. 81-100, 2008.

. Uma articulação da análise de discurso com a história das ideias linguísticas. Letras (UFSM), Santa Maria, v. 18, n. 2, p. 107-124, jul./ dez. 2008a.

. Leitura de arquivo: historicidade e compreensão. In: M. C. L. Ferreira, F. Indursky (orgs.). Análise do discurso no Brasil: mapeando conceitos, confrontando limites. São Carlos: Claraluz, 2007. p. 373-380.

- Definição lexicográfica e discurso. Língua e Instrumentos Linguísticos. Campinas, v. 11, n.11, p. 09-30, 2003.

. "Dicionarização no Brasil: condição e processos". In: Nunes, José Horta; Petter, Margarida (Orgs.) História do saber lexical: constituição de um léxico brasileiro. SP: Humanitas; Campinas: Pontes, 2002.

ORLANDI, Eni P. Lexicografia Discursiva. Alfa: Revista de Linguística (UNESP. Impresso). v. 44, p. 97-114, 2000.

, Eni P. Língua e conhecimento linguístico: para uma história das ideias no Brasil. São Paulo, Cortez, 2002. 